\title{
Pengaruh Alelokimia Ekstrak Daun Kirinyuh (Chromolaena odorata L.) Terhadap Pertumbuhan Vegetatif Kedelai [Glycine max (L.) Merr]
}

\section{The Effect of Kirinyuh Leaf (Chromolaena odorata L.) Extract to Vegetative Growth of Soybean [Glycine $\max$ (L.) Merr]}

\author{
Siti Umi Shofiyatin' Sri Widodo Agung Suedy' Sri Darmanti* \\ Program Studi Biologi, Fakultas Sains dan Matematika Universitas Diponegoro \\ *Email : darmantisri@yahoo.co.id
}

Diterima 7 Agustus 2020 /Disetujui 1 September 2020

\begin{abstract}
ABSTRAK
Gulma merupakan tumbuhan yang tidak dikehendaki kehadirannya karena berpotensi alelopati. Alelopati merupakan interaksi antar tanaman dengan perantaraan senyawa alelokimia yang dilepaskan ke lingkungan. Alelokimia dapat menghambat pertumbuhan tanaman di sekitarnya. Kirinyuh (Cromolaena odorata L.) adalah salah satu gulma yang banyak dijumpai di berbagai lahan budidaya. Kedelai [Glycine max (L.) Merr ] merupakan komoditas pertanian sumber pangan yang berprotein tinggi. Keberadaan gulma, termasuk diantaranya $C$. odorata merupakan salah satu kendala penting dalam meningkatkan pertumbuhan dan produksi kedelai. Penelitian ini bertujuan mengkaji pengaruh alelokimia ekstrak daun $C$. odorata $\mathrm{L}$. terhadap pertumbuhan vegetatif tanaman kedelai. Penelitian menggunakan Rancangan Acak Lengkap (RAL) faktor tunggal berupa konsentrasi ekstrak daun C. Odorata yaitu 0\%, 20\%, 40\%, 60\% dan 80\%, tiap unit perlakuan dengan lima ulangan. Data kuantitatif dianalisis dengan Analysis of Variance (ANOVA) dan dilanjut dengan uji Duncan's Multiple Range Test (DMRT) pada taraf kepercayaan 95\% $(\alpha=5 \%)$. Hasil penelitian menunjukkan bahwa alelokimia pada ekstrak daun gulma kirinyuh ( $C$. odorata L.) berpotensi menghambat pertumbuhan vegetataif tanaman kedelai. Penurunan kandungan klorofil total dan pertumbuhan vegetatif secara efektif terjadi mulai konsentrasi ekstrak $40 \%$ dan semakin tinggi konsentrasi ekstrak, penurunan nilai parameter yang diukur semakin besar.
\end{abstract}

Kata Kunci: alelopati, alelokimia, gangguan gulma.

\begin{abstract}
Weed is an unwanted plant because of its allelopathy potential. Allelopathy is the interaction between plants with the mediation of allelochemical compounds released into the environment. Allelochemicals can inhibit the growth of plants around them. Kirinyuh (Cromolaena odorata L.) is one of the weeds that are often found in various cultivated lands. Soybean [Glycine $\max$ (L.) Merr] is a high-protein agricultural commodity. The presence of weeds, including $C$. odorata is one of the important obstacles in increasing soybean growth and production. This study aims to examine the effect of allelochemicals of $C$. odorata L. leaf extract on soybean vegetative growth. The study used a single complete randomized design (CRD) in the form of concentrations of $C$. odorata L. leaf extracts namely $0 \%, 20 \%, 40 \%, 60 \%$ and $80 \%$, each treatment unit with five replications. Quantitative data were analyzed by Analysis of Variance (ANOVA) and followed by Duncan's Multiple Range Test (DMRT) at a 95\% confidence level $(\alpha=5 \%)$. The results showed that the allelochemicals in the leaf extract of kirinyuh weed (C. odorata L.) had the potential to inhibit the vegetative growth of soybean plants. Total chlorophyll content and vegetative growth decrease effectively on the $40 \%$ extract and the higher the concentration of the extract, the greater the measured parameter value decreases.
\end{abstract}

Keywords : allelopathy, allelochemicals, weed interference 


\section{PENDAHULUAN}

Kedelai [Glycine max (L.) Merr ] merupakan komoditas pertanian sumber pangan yang berprotein tinggi. Permintaan biji kedelai sebagai bahan dasar berbagai makanan terus meningkat. Kedelai cv. Grobogan merupakan kedelai lokal Kabupaten Grobogan yang dilepas Menteri Pertanian tahun 2008. Keunggulan kedelai cv. Grobogan diantaranya adalah kandungan protein yang cukup tinggi, yaitu sekitar $43,6 \%$, memiliki polong berukuran besar dan berbunga pada umur 30-32 hari. Cekaman kekeringan dan gangguan gulma yang terjadi selama periode pertumbuhan kedelai merupakan kendala serius dalam usaha meningkatkan produksi kedelai di Indonesia (Darmanti et al., 2016). Menurut Morvilo et al. (2011) gangguan gulma terhadap tanaman budidaya seperti kedelai dapat melalui kompetisi terhadap faktor tumbuh dan peristiwa alelopati.

Gulma merupakan tumbuhan yang tumbuh liar pada lahan budidaya atau tumbuhan yang tidak dikehendaki keberadaannya karena dapat menimbulkan kerugian, sehingga keberadaan gulma perlu dikendalikan (Sindel dan Coleman 2010). Kehadiran gulma pada pertanaman budidaya dapat menghambat pertumbuhan, menjadi inang hama dan penyakit serta menurunkan hasil panen. Menurut Thamrin dkk (2013), Kirinyuh (Cromolaena odorata L.) adalah salah satu gulma yang sering tumbuh pada lahan budidaya kedelai. Prawiradiputra (2007), menyatakan bahwa gulma C. odorata L. merupakan tumbuhan semak berkayu yang dapat berkembang dengan cepat dan membentuk kelompok yang dapat mencegah perkembangan tumbuhan lainnya. Gulma $C$. odorata L.ini merupakan pesaing agresif dan memiliki potensi alelopati.

Alelopati adalah pengaruh satu tanaman terhadap tanaman yang lain melalui pelepasan senyawa kimia ke lingkungan (Kelton et al., 2012). Senyawa kimia yang dilepaskan disebut alelokimia. Alelokimia merupakan senyawa kimia yang dihasilkan oleh suatu tanaman yang dapat mengganggu tanaman disekitarnya, sehingga dapat menyebabkan pertumbuhan tanaman menjadi terhambat. Djazuli (2011) melaporkan bahwa ekstrak kirinyuh mengandung beberapa senyawa kimia yaitu alkaloid, flavonoid, tanin, fenol, dan limonen. Beberapa dari senyawa-senyawa kimia tersebut merupakan senyawa alelokimia yang dapat menghambat pertumbuhan tanaman lain. Sedangkan Hadi dkk (2000), menunjukkan bahwa ekstrsk daun kirinyuh mengandung $66 \%$ senyawa monoterpen, 28\% sesquiterpen, $11-17 \% \alpha$-pinene, $12,5-24,8 \%$ cymene serta $10 \%$ thymyl acetate.

Senyawa alelokimia pada tumbuhan dapat dilepaskan dalam berbagai cara, yaitu melalui penguapan, eksudat akar, pencucian dan dekomposisi residu yang dapat terjadi di alam maupun pada sistem pertanian (Ferguson dan Rathinasabapathi, 2009). Menurut Sharma et al. (2012), mekanisme pengaruh alelokimia dalam menghambat pertumbuhan dan perkembangan tumbuhan melalui proses yang kompleks. Proses tersebut diawali dengan terjadinya perubahan struktur membran plasma, modifikasi saluran membran, atau hilangnya fungsi enzim ATP-ase. Proses ini akan berpengaruh terhadap penyerapan ion dan air yang kemudian mempengaruhi pembukaan stomata dan proses fotosintesis yang akhirnya menghambat pertumbuhan dan perkembangan tanaman. Menurut Ferguson dan Rathinasabapathi (2009), senyawa alelokimia berupa fenol dan flavonoid dapat mempengaruhi penyerapan hara, pembelahan sel, penghambat pertumbuhan, fotosintesis, respirasi, sintesis protein dan aktivitas enzim. Hal ini sesuai dengan pendapat Singh et al. (2009), bahwa alelokimia menyebabkan penurunanan aktivitas enzim H+ATPase yang menyebabkan membran kehilangan integritasnya sehingga mengakibatkan kehilangan elektrolit, penghambatan ion tertentu dan gangguan sintesis pigmen. Sedangkan Moosavi et al. (2011), menyatakan bahwa alelokimia memiliki efek terhadap mitokondria yang menyebabkan gangguan fungsi respirasi dan gangguan aktivitas hormon. Dari latar belakang diatas, maka permasalahan yang dikaji dalam penelitian ini adalah bagaimanakah pengaruh alelokimia esktak daun $C$. odorata $\mathrm{L}$. terhadap pertumbuhna tanaman kedelai.

\section{METODE PENELITIAN}

Bahan utama yang digunakan adalah benih kedelai [Glycine $\max (\mathrm{L}$.) Merr] cv. Grobogan yang 
diperoleh dari Balai Penelitian Kacang-Kacangan dan Umbi-Umbian (BALITKABI) Malang, Jawa Timur, daun Kirinyuh (Cromolaena odorata L.) diperoleh dari lingkungan kampus Universitas Diponegoro. Alat utama yang digunakan adalah spektrofotometer UV-Vis dan mikroskop optilab.

\section{Estraksi Daun C. odorata $\mathrm{L}$}

Daun C. odorata L. dikeringanginkan selama 24 jam pada kondisi gelap, kemudian dihaluskan dengan menggunakan blender, diekstraksi dengan akuades dan disaring dua kali menggunakan kertas saring. Untuk mendapatkan ekstrak konsentrasi $100 \%$ dibuat dengan perbandingan daun dan akuades dengan rasio 1:1 berat/volume. Ekstrak yang diperoleh disimpan di tempat gelam dengan suhu rendah (Darmanti et al., 2015). Untuk mendapatkan ekstrak dengan konsentrasi perlakuan yatu $80 \%, 60 \%, 40 \%, 20 \%$ dan $0 \%$ (kontrol), ekstrak konsentrasi $100 \%$ diencerkan dengan akuades.

\section{Penanaman dan Perlakuan}

Benih kedelai diseleksi berdasarkan keseragaman bentuk dan ukuran. Lima benih kedelai ditanam dalam poly bag dengan media tanam berupa campuran tanah, sekam dan kompos dengan perbandingan 2:1:1. Setelah tujuh hari, pada tiap poly bag dipilih satu batang bibit kedeai. Seleksi bibit kedelai berdasarkan atas keseragaman tinggi tajuk dan jumlah daun. Perlakuan alelokimia ekstrak daun $C$. Odorata L. dilakukan setiap dua hari sekali, dimulai pada hari ke 11 sampai hari ke 21 dengan menyemprotkan $10 \mathrm{ml}$ ekstrak daun C.odorata L. pada seluruh bagian tanaman kedelai. Pemeliharaan berupa penyiraman dilakukan setiap hari pada sore hari, dengan volume air sama pada semua tanaman. Penyiangan gulma dilakukan secara manual setiap tujuh hari.

\section{Parameter penelitian}

Parameter yang diamati adalah kandungan klorofil total dan karotenoid, bobot kering tajuk dan akar, jumlah daun dan rasio tajuk-akar berdasarkan bobot kering. Parameter dihitung pada saat perlakuan dihentikan, yaitu 21 hari setelah perlakuan. Penentuan kandungan klorofil total dan karotenoid berdasarkan metode Hendry and Grime (1993) seperti yang digunakan oleh Kurniawan dkk (2010).

Klorofil Total (mg/L)

$=8,02\left(A_{663}\right)+20,2\left(A_{645}\right) \mathrm{mg} / \mathrm{l}$

Karotenoid (mg/L)

$$
=\frac{\llbracket\left\{\left(\mathrm{A} \rrbracket_{480}+\left(0.114 \times \mathrm{A} \rrbracket_{663}-0.638 \times \mathrm{A}_{645} \llbracket\right) \times \mathrm{V} \times 10^{3}\right)\right\}}{112,5 \times 0,1 \times 10}
$$

Data yang diperoleh di analisis menggunakan Uji Anova dengan taraf kepercayaan 95\%. Jika hasil yang diperoleh berbeda nyata maka dilakukan uji lanjut berupa uji Duncan dengan taraf uji 5\%.

\section{HASIL DAN PEMBAHASAN}

Hasil penelitian menunjukan bahwa alelokimia ekstrak daun $C$. odorata $\mathrm{L}$. berpengaruh menurunkan kandungan klorofil total, namun tidak perpengaruh terhadap kandungan karotenod daun kedelai cv. Grobogan. Penurunan kandungan klorofil total terjadi pada perlakuan ektrak konsentrasi 40\%, 60\% dan 80\%, sedangkan pada perlakuan konsentrasi $20 \%$ tidak menunjukan perbedaan yang nyata dibandingkan kontrol $(0 \%)$. Kandungan karotenoid pada semua perlakuan tidak menunjukan perbedaan yang nyata dibandingkan dengan kontrol, tetapi terdapat kecenderungan terjadi menurunkan kandungan karotenoid akibat perlakuan ekstrak daun $C$. odorata L. Nilai tertinggi kandungan klorofil total dan karotenoid pada perlakuan kontrol, dan semakin tinggi konsentrai perlakuan kandungan klorofil total dan karotenoid semakin rendah (Tabel 1).

Penurunan klorofil total pada hasil penelitian ini (Tabel 1) disebabkan oleh peghambatan sintesis klorofil oleh alelokimia dari ekstrak daun C. Odorata L. Menurut Li et al. (2010) dan Sharma et al. (2012) pada peristiwa alelopati, alelokimia dari satu tanaman akan direspon oleh tanaman target dengan mensintesis radikal bebas atau Reactive oxygen species (ROS) dalam jumlah berlebih. Radikal bebas yang berlebih tersebut dapat menyebabkan terjadinya cekaman oksidatif yang antara lain berupa perubahan permeabilitas membran sel, sehingga 
dapat mengganggu penyerapan air dan hara terlarut. Sintesis klorofil antara lain dipengaruhi oleh faktor genetik, cahaya, air, suhu dan unsur hara seperti $\mathrm{N}$, $\mathrm{Mg}, \mathrm{Fe}, \mathrm{Mn}, \mathrm{Cu}, \mathrm{Zn}, \mathrm{S}$, dan O. Pada tanaman, unsur hara nitrogen akan dikonversi oleh enzim sintetase asam glutamin menjadi asam glutamat dan asam glutamat digunakan dalam biosintesis klorofil (Khang et al., 2016; Kusumawardani et. al., 2018). Selain karena hal tersebut, Yang et. al. (2002) mengemukaan bahwa penurunan kandungan klorofil pada peristiwa alelopati juga disebabkan karena meningkatnya aktivitas enzim pendegradasi klorofil dan menurunnya aktivitas enzim yang bekerja pada reaksi sintesis klorofil. Hasil penelitian ini menunjukkan, kandungan karotenoid pada semua perlakuan tidak berbeda nyata tetapi cenderung menurunkan nilai kadar karotenoid. Hal ini terjadi karena sintesis klorofil berhubungan dengan karotenoid karena proses sintesisnya diregulasi oleh fotoreseptor yang sama yaitu fitokrom (Campbell et al, 2010). Apabila sintesis klorofil terhambat maka berdampak pula pada sintesis karotenoid. Menurunnya kandungan klorofil dan karotenoid pada tanaman kedelai cv.Grobogan tersebut secara langsung akan menurunkan aktivitas fotosintesis dan fotosintat, yang pada akhirnya akan mempengaruhi pertumbuhan tanaman target.

Tabel 1. Kandungan Klorofil Total dan Karotenoid Daun Kedelai (Glycine max (L.) Merr ) cv. Grobogan setelah perlakuan alelokimia ekstrak daun C. odorata L. selama 21 hari

\begin{tabular}{ccc}
\hline Konsentrasi ekstrak (\%) & Klorofil Total (mg/l) & Karotenoid (mg/l) \\
\hline 0 & $24.25^{\mathrm{a}}$ & $0.75^{\mathrm{a}}$ \\
20 & $23.90^{\mathrm{ab}}$ & $0.73^{\mathrm{a}}$ \\
40 & $24.45^{\mathrm{bc}}$ & $0.73^{\mathrm{a}}$ \\
60 & $21.22^{\mathrm{cd}}$ & $0.72^{\mathrm{a}}$ \\
80 & $20.20^{\mathrm{d}}$ & $0.67^{\mathrm{a}}$ \\
\hline
\end{tabular}

Keterangan : Angka pada kolom yang sama, yang diikuti huruf yang berbeda menunjukan perbedaan yang nyata dengan uji lanjut DMRT pada taraf uji $5 \%$.

Hasil penelitian menunjukan perlakuan alelokimia ekstrak daun C. Odorata L. berpengaruh menurunkan pertumbuhan tanaman kedelai cv. Grobogan ditinjau dari parameter bobot segar dan bobot kering tajuk serta bobot segar dan bobot kering akar. Penurunan bobot segar tajuk secara nyata terjadi pada perlakuan konsentrasi ekstrak $40 \%$, sedangkan penurunan bobot kering terjadi mulai perlakuan konsentrasi $20 \%$. Sebaliknya penurunan bobot segar akar secara nyata terjadi pada perlakuan konsentrasi ekstrak $20 \%$ dan penurunan bobot kering terjadi mulai perlakuan konsentrasi $40 \%$. Pada semua parameter bobot tajuk maupun akar ini menunjukkan bahwa semakin tinggi konsentrasi perlakuan bobot segar dan bobot kering semain turun (Tabel 2).

Hasil analisis data menunjukkan bahwa alelokimia ekstrak daun $C$. odorata $\mathrm{L}$. berpengaruh nyata menurunkan tinggi tanaman, luas daun dan jumlah daun kedelai. Semakin tinggi konsentrasi perlakuan, penurunan semakin banyak. Tinggi tanaman kedelai mulai turun pada konsentrasi perlakuan $20 \%$, sedangkan luas daun dan jumlah daun mulai turun pada konsentrasi perlakuan $40 \%$ (Tabel 3). Penurunan pertumbuhan tanaman kedelai cv. Grobogan akibat perlakuan alelokimia ekstrak daun C. odorata L. terjadi pada semua parameter pertumbuhan yang diukur. Menurut Gomes et al. (2017), alelokimia menyebabkan turunnya aktivitas akar dalam menyerap hara sehingga proses fotosintesis terganggu. Sel-sel akar memiliki struktur membran sel yang tersusun oleh fosfolipid bilayer, protein, dan karbohidrat. Senyawa alelokimia terutama fenol akan menempel pada lipid penyusun membran sel. Hal tersebut akan menyebabkan kelarutan lemak menjadi menurun yang mengakibatkan kerusakan membran sel, dan berdampak pada organel yang berada didalam sel yaitu mitokondria, kloroplas, dan vakuola. Penghambatan rantai transpor elektron pada mitokondria dan kloroplas akan menghilangkan sumber energi sel yang berupa NADPH, FAD dan ATP, produk metabolik, dan juga menghasilkan ROS (Zhou and Yu, 2006; Shannon-Firestone and 
Firestone, 2015). Dengan menghilangnya sumber energi sel ini, maka pembentukan klorofil yang terhambat mengakibatkan proses fotosintesis turun, metabolit primer turun dan pertumbuhan terhambat. Terhambatnya aktivitas kloroplas didalam sel dapat mempengaruhi sintesis klorofil dan karotenoid. Hal ini sesuai dengan penelitian yang dilakukan oleh Maqbool and Sadiq (2017), bahwa alelokimia ekstrak daun sorgum menurunkan kadar klorofil tanaman jagung.

Tabel 2. Bobot segar serta bobot kering tajuk dan akar Kedelai (Glycine max (L.) Merr ) cv. Grobogan setelah perlakuan alelokimia ekstrak daun $C$. odorata L selama 21 hari.

\begin{tabular}{ccccc}
\hline $\begin{array}{c}\text { Konsentrasi } \\
\text { Esktrak }(\%)\end{array}$ & \multicolumn{2}{c}{ Tajuk } & \multicolumn{2}{c}{ Akar } \\
\cline { 2 - 5 } & $\begin{array}{c}\text { Bobot Segar } \\
(\mathbf{g})\end{array}$ & $\begin{array}{c}\text { Bobot Kering } \\
(\mathbf{g})\end{array}$ & $\begin{array}{c}\text { Bobot Segar } \\
(\mathbf{g})\end{array}$ & $\begin{array}{c}\text { Bobot Kering } \\
(\mathbf{g})\end{array}$ \\
\hline 0 & $5.81^{\mathrm{a}}$ & $1.28^{\mathrm{a}}$ & $0.91^{\mathrm{a}}$ & $0.18^{\mathrm{a}}$ \\
20 & $5.40^{\mathrm{a}}$ & $1.15^{\mathrm{b}}$ & $0.76^{\mathrm{b}}$ & $0.17^{\mathrm{a}}$ \\
40 & $4.44^{\mathrm{b}}$ & $1.01^{\mathrm{c}}$ & $0.58^{\mathrm{c}}$ & $0.15^{\mathrm{b}}$ \\
60 & $4.30^{\mathrm{b}}$ & $0.89^{\mathrm{d}}$ & $0.56^{\mathrm{c}}$ & $0.15^{\mathrm{b}}$ \\
80 & $4.00^{\mathrm{b}}$ & $0.87^{\mathrm{d}}$ & $0.45^{\mathrm{c}}$ & $0.12^{\mathrm{c}}$ \\
\hline
\end{tabular}

Keterangan : Angka pada kolom yang sama, yang diikuti huruf yang berbeda menunjukan perbedaan yang nyata dengan uji lanjut DMRT pada taraf uji 5\%.

Tabel 3. Tinggi Tanaman, Luas Daun, dan jumlah daun Kedelai (Glycine max (L.) Merr) cv. Grobogan setelah perlakuan alelokimia ekstrak daun $C$. odorata L selama 21 hari.

\begin{tabular}{cccc}
\hline Konsentrasi ekstrak (\%) & Tinggi Tanaman $(\mathrm{cm})$ & Luas Daun $\left(\mathrm{cm}^{2}\right)$ & Jumlah Daun \\
\hline 0 & $110,7^{\mathrm{a}}$ & $20,22^{\mathrm{a}}$ & $18,00^{\mathrm{a}}$ \\
20 & $99,1^{\mathrm{b}}$ & $18,20^{\mathrm{ab}}$ & $17,75^{\mathrm{a}}$ \\
40 & $97,7^{\mathrm{b}}$ & $17,07^{\mathrm{bc}}$ & $16,00^{\mathrm{b}}$ \\
60 & $94,3^{\mathrm{b}}$ & $16,80^{\mathrm{c}}$ & $14,75^{\mathrm{b}}$ \\
80 & $74,8^{\mathrm{c}}$ & $15,52^{\mathrm{c}}$ & $14,75^{\mathrm{b}}$ \\
\hline
\end{tabular}

Keterangan : Angka pada kolom yang sama, yang diikuti huruf yang berbeda menunjukan perbedaan yang nyata dengan uji lanjut DMRT pada taraf uji $5 \%$.

Alelokimia juga mempunyai banyak pengaruh fitotoksik yang menyebabkan turunnnya pertumbuhan tanaman target. Penurunan aktivitas enzim $\mathrm{H}^{+}$ATPase pada membran sel merupakan gangguan pertama yang menyebabkan terjadinya absorpsi anion dan kation non spesifik. Hal tersebut berkorelasi dengan terhambatnya absorbsi ion tertentu seperti fosfat, nitrat dan magnesium (Einhelig, 2004). Hambatan terhadap sintesis klorofil dan memicu peningkatan degradasi klorofil (Yang et al., 2002), hambatan sintesis karotenoid (Gniazdowska and Bogatek 2005) serta gangguan transport elektron pada fotosistem II (FS II). Semua gangguan tersebut berpengaruh secara langsung pada menurunnya laju fotosintesis dan pertumbuhan tanaman target, baik berupa pertumbuhan organ batang, akar amupun duan.

Menurut Weraduwage et al., (2015) bobot segar tanaman dapat menunjukkan aktivitas metabolisme primer tanaman dan nilai bobot bsegar tanaman dipengaruhi oleh kandungan air, unsur hara dan hasil fotosintesis. Pengaruh alelokimia dalam menurunkan nilai bobot segar dengan menurunkan kecepatan penyerapan air dan hasil fotosintesis. Menurut Yulifrianti et al. (2015), hambatan penyerapan air oleh senyawa fenol menyebabkan kadar air menjadi rendah akibatnya terjadi penutupan stomata, sehingga proses fotosintesis terhambat. Alelokimia mempengaruhi fotosintesis dan pertumbuhan tanaman dengan menurunkan kandungan klorofil. Penurunan kapasitas tanaman untuk mengakumulasi klorofil yang merupakan komponen penting dalam proses fotosintesis mampu mempengaruhi penurunan bobot segar dan bobot kering tanaman. Menurut Salisbury dan Ross (1995), penyerapan garam mineral sebagian dikendalikan oleh tajuk. Tajuk akan merangsang akar untuk meningkatkan 
penyerapan garam mineral dan secara cepat menggunakan garam mineral tersebut dalam pembentukan protein, asam nukleat dan klorofil. Tajuk memasok karbohidrat melalui floem yang digunakan akar untuk melakukan respirasi yang akan menghasilkan ATP. Sehingga menghasilkan bobot tajuk yang lebih tinggi daripada akar.

\section{KESIMPULAN}

Alelokimia gulma kirinyuh ( $C$. odorata L.) berpotensi menghambat pertumbuhan vegetataif tanaman kedelai. Penurunan kandungan klorofil total dan pertumbuhan vegetatif tanaman kedelai secara efektif terjadi mulai konsentrasi ekstrak $40 \%$ dan semakin tinggi konsentrasi ekstrak daun penurunan nilai parameter yang diukur semakin besar.

\section{DAFTAR PUSTAKA}

Campbell, N.A. J.B Reece, L.G. Mitchell. 2010. Biologi. Alih bahasa :L.Rahayu, E.I.Adil, N Anita, Andri, W.F Wibowo, W. Manalu Jakarta : Erlangga.

Darmanti, S., Santosa, Kumala D. and Hartanto N. 2015. Allelopathic Effect of Cyperus rotundus L. on Seed Germinationand Initial Growth of Glycine max (L.) cv. Grobogan. Jurnal Bioma 17(2): 61-67

Darmanti S., santosa, K. Dewi and L. H. Nugroho. 2016. Antioxidative Defenses of Soybean [Glycine $\max$ (L.) Merr. cv. Grobogan] Againts Purple nutsedge (Cyperus rotundus L.) Interference During Drought Stress. Journal of Animal and Plant Sciences. 26 (1). $225-232$.

Djazuli, M. 2011. Alelopati pada bebera patanaman perkebunan dan tekhnik pengendalian serta prospek pemanfaatannya. Prospektif 10 (1): 44-50.

Einhellig, F.A. 2004. Mode of Allelochemical Action of Phenolic Compounds. pp. 217238. In F.A.Macias, J.C.G. Galindo, J.M.G. Molinillo and H.G. Cutler (Eds.). Allelopathy : Chemistry and Mode of Action of Allelochemicals. CRC Press, New York.
Ferguson, J.J.,and B. Rathinasabapathi. 2009. Allelopathy: How Plants Suppress Other Plants. Horticultural Sciences Department, Florida Cooperative Extension Service, Institute of Food and Agricultural Sciences, University of Florida.

Gniazdowska, A. and R. Bogatek. 2005. Allelopathic Interaction Between Plants : Multi Site Action of Allelochemicals. Acta Physioloiyae Plantaraum. 27: 395-407.

Gomes, M.P., Queila, S.G., Leilane, C.B., Lucia, P.S.P., Miele, T.M., and Cleber.C.F. 2017. Allelopathy: An overview from micro- to macroscopic organisms, from cells to environments, and the perspectives in a climate-changing world. Biologia. 72(2): 113-129.

Hadi, M, J.W. Hidayat dan K. Baskoro, 2000. Uji Potensi Ekstrak Daun Euphataorium odoratum Sebagai Bahan Insektisida Alternatif : Toksisitas dan Efek Anti Makan Terhadap Larva Heliotis armigera Hubner. Jurnal Sain dan Matematika. 6(2):12-18.

Hendry, G. A. F., dan J. P. Grime., 1993. Methods on Comparative Plant Ecology, a laboratory manual. London : Chapman and Hill.

Kelton, J., Andrew J., Kelton and Jorge M. 2012. Weed Control. Intech. USA.

Khang, Do Tan, La H. A., Pham.T .T. H., Phung. T. T. 2016. Allelopathic Activity of Dehulled Rice and its Allelochemicals on Weed Germination. International Letters of Natural Sciences Submitted. 58:1-10 ISSN: 2300-9675.

Kurniawan M., M Izzati. dan Y Nurchayati. 2010. Kandungan Klorofil, Karotenoid, dan Vitamin C pada Beberapa SpesiesTumbuhan Akuatik. Buletin Anatomi dan FisiologiVol. 18 (1) : $28-40$

Li, X. and C. Chapple. 2010. Understanding Lignification : Challenges Beyond Monolignol Biosynthesis. Plant Physiology. 154 : 449-452

Maqbool, N. and R. Sadiq. 2017. Allelochemicals as Growth Stimulators for Drought Stressed 
Maize. American Journal of Plant Sciences, 8, 985-997

Morvillo, C.M., E.B. de la Fuente, A. Gil, M.A. Martinez-Ghersa and J.I. Gonzalez-Andujar. 2011. Competitive and Allelopathic Interference between Soybean Crop and Annual Wormwood (Artemesia annua L.) under Field Conditions. European Journal of Agronomy. 34 : 211-221.

Moosavi A., R. T. Afshari, A. Asadi and M. H. Gharineh. 2011. Allelopathic Effect of Aqueous Extract of Leaf Stem and Root of Sorgum bicolor on Seed germination and Seedling Growth of Vigna radiata L. Not. Sci. Biol. 3(2):114-118.

Prawirodiputra, B. R. 2007. Kirinyuh (Chromolaena odorata L.) : Gulma Padang Rumput yang Merugikan. Bulletin Ilmu Peternakan Indoneaia WARTAZOA. 17(1):46-52

Salisbury, F.B. dan C. W. Ross. 1995. Fisiologi Tumbuhan Jilid 1. ITB Press, Bandung.

Shannon-Firestone S. and J. Firestone. 2015. Allelopathic Potential of Invasive Spesies is Determined by Plant and Soil Community Context. Plant Ecol. 216: 491-502.

Sharma, P., A.B. Jha, R.S. Dubey and M. Pessarakli. 2012. Reactive Oxygen Species, Oxidative Damage and Antioxidative Defense Mechanism in Plant Under Stressful Conditions. Review Article. J. Bot. Vol 2012. Article ID $217037 . \quad$ doi: 10.1155/2012/217037.

Singh, N.B., B.N. Pandey and A. Sigh. 2009. Allelopathic Effects of Cyperus rotundus Extract in Vitro and ex Vitro on Banana. Acta Physiologiae Plantarum. 31 : 633-638
Sindel, B., and Coleman, M. 2010. Weed Detection and Control on Small Farms. Australia Government. Australia.

Thamrin, M., S. Asikin, dan M. Willis. 2013. Tumbuhan Kirinyuh (Chromolaena odorata L.) Sebagai Insektisida Nabati Untuk Mengendalikan Ulat Grayak Spedoptera litura. Jurnal Litbang Pertanian. 32(3):112121.

Wardani D.K., S. Darmanti, R. Budihastuti. 2018. Allelochemicals Effect of Ageratum conyzoides L. Leaft Extract on Sybean [Glycine $\max$ (L.) Merr. cv. Grobogan] Gorwth. IOP Conf. Series: Journal of Physics: Conf. Series 1025 : 012044

Weraduwage, S. M., C. Jin and D.S. Thomas. 2015. The Relationship Between Leaf Area Growth and Biomassa Accumulation in Arabidopsis thaliana. Front. Plant Science. $6: 167$

Yang, C.M, C.N. Lee and C.H. Chou. 2002. Effect of Three Allelopathic Phenolics on Chlorophyll Accumulation of Rice (Oryza sativa) Seedlings : I. Inhibitation of Supply - Orientation. Botanical Bulletin Academia Sinsinica. 43 : 299-304.

Yulifrianti, E., L. Riza dan L. Irwan. 2015. Potensi Alelopati Ekstrak Serasah Daun Mangga (Mangifera indica L.) Terhadap Pertumbuhan Gulma Rumput Grinting (Cynodon dactylon L.) Press. Jurnal Protobiont. 4 (1) : $46-51$

Zhou Y.H. and Yu J.Q. 2006. Allelochemicals and photosynthesis,. In: Reigosa M.J. Pedrol N. and Gonzales L. (eds). Allelopathy. Springer Netherlands. pp. 127-139 